\title{
Behavioral Responses of Households to Tax Reforms
}

\author{
Ivan Kirsanov*, Lyudmila Parfyonova \\ Faculty of Economics, P. G. Demidov Yaroslavl State University, Russia \\ Received September 1, 2021; Revised October 10, 2021; Accepted November 11, 2021
}

\section{Cite This Paper in the following Citation Styles}

(a): [1] Ivan Kirsanov, Lyudmila Parfyonova , "Behavioral Responses of Households to Tax Reforms," Universal Journal of Accounting and Finance, Vol. 9, No. 6, pp. 1454-1469, 2021. DOI: 10.13189/ujaf.2021.090622.

(b): Ivan Kirsanov, Lyudmila Parfyonova (2021). Behavioral Responses of Households to Tax Reforms. Universal Journal of Accounting and Finance, 9(6), 1454-1469. DOI: 10.13189/ujaf.2021.090622.

Copyright@2021 by authors, all rights reserved. Authors agree that this article remains permanently open access under the terms of the Creative Commons Attribution License 4.0 International License

\begin{abstract}
Over the past 10 years, significant reforms have taken place in the Russian tax area. Households are under the influence caused by the following changes: the rules for property and land tax recalculating according to the cadastre data including summer cottages and garages in the list of taxable objects, the transport tax on luxury cars, and the introduction of a progressive personal income tax scale. Accordingly, the purpose of this article is to examine the response of households to changes in tax policy and to interpret this response using behavioral approach. The key hypothesis of the study is that households demonstrate varying degrees of reaction to any changes in tax legislation. Likewise, in the context of the deteriorating fiscal environment, households seek to optimize the tax burden. The authors analyzed the theoretical and methodological basis of this topic, which allowed the authors to propose improvements in methods of studying households. The study was conducted on the basis of data on payments of taxes by the Russian households. The authors revealed the features of the relationship of tax payments and different economic indicators. It is established by the Pearson correlation coefficient that there are varying degrees of households' reaction to changes in tax legislation, and households' responses are not uneven for all types of taxes. Authors also calculated the coefficient of elasticity of tax payments depending on various factors. The approach given in the article is needed for a more complete understanding of how effects of tax changes to households may be used to create effective techniques and measures in tax policy. This study makes unique contributions to further
\end{abstract}

researches in the area, which will lead to the introduction of new mechanisms for state programs in tax area and forecast their implementation for the medium- and longterms.

Keywords Tax Policy, Households, Tax Reform, Behavioral Economics, Pearson Correlation Coefficient, Russia

\section{Introduction}

In Russia households have been challenging times from a financial perspective over the past seven years. The socioeconomic problems, crises, structural imbalances have developed a number of contradictory trends in the field of personal finance of households. There are households with completely diverse financial behaviors due to an extremely high level of social stratification in the country. Obviously, the conditions for the taxation of households are increasingly changing. Therefore, the subject of our study is the peculiarities of the households' reaction to changes in tax legislation.

A systematic tax reform has been underway for more than 15 years. We have studied all the changes in tax legislation on personal income tax, property tax, land tax and transport tax. We have systematized data on the number of changes and determined the importance of certain ones (Table 1). 
Table 1. Critical changes in the household taxation in the Russian Federation in 2006-2021

\begin{tabular}{|c|c|}
\hline Tax & Key changes \\
\hline Personal income tax & $\begin{array}{l}\text { 1. Imposition of a progressive taxation scale (in 2021). In Russia from January } 1,2021 \text { income up to a } \\
\text { limit of } 5 \text { million rubles (equal to } \$ 68 \text { thousand) is taxed at a rate of } 13 \% \text {, the tax rate of } 15 \% \text { is for } \\
\text { over limit amounts. It is important to note that the received extra funds go to a special fund for the } \\
\text { provision of medical care to children with serious illnesses. } \\
\text { 2. From } 2021 \text { interest on deposits exceeding the non-taxable least at one million rubles will be taxed } \\
\text { to personal income tax at a rate of } 13 \% \text {. } \\
\text { 3. In } 2016 \text { the least five-year term of ownership of real estate for exemption from personal income tax } \\
\text { changed to three-year term. } \\
\text { 4. Since } 2015 \text { several types of investment tax deductions have introduced for transactions with } \\
\text { securities. } \\
\text { 5. In } 2014 \text { there was the opportunity to take advantage of the property tax deduction of } 2 \text { million } \\
\text { rubles at the time of the adoption of the law [1]. }\end{array}$ \\
\hline Individual land tax & $\begin{array}{l}\text { 1. The result of the cadastral evaluation in } 2020 \text { is changing the rules for recalculating and challenging } \\
\text { the cadastral value in } 2018 \text {, establishing a new mechanism for pretrial. } \\
2 \text {. In } 2014 \text { the system for assessing the value of land plots of individuals under the cadastral } \\
\text { registration data began to work [1]. }\end{array}$ \\
\hline $\begin{array}{l}\text { Transport tax on natural } \\
\text { persons }\end{array}$ & $\begin{array}{l}\text { 1. The introduction of higher tax rates for luxury cars in } 2014 \text { and } 2015 \text {. A special increased scale of } \\
\text { taxation approved for listed annually luxury cars with the highest value. } \\
\text { 2. In } 2018 \text { there was an expansion of the list of cars and further increase in payments [1]. }\end{array}$ \\
\hline Personal property tax & $\begin{array}{l}\text { 1. In } 2014 \text { the deflator coefficient began to use for the indexation of tax payments regardless of the } \\
\text { economic situation. The deflator coefficient takes into account changes of consumer price for goods } \\
\text { and services in Russia. Annually the deflator coefficient officially is determined by the Government of } \\
\text { the Russian Federation. } \\
\text { 2. In } 2015 \text { a system for assessing the value of property of individuals under the cadastral registration } \\
\text { data began to work. } \\
\text { 3. In } 2020 \text { expansion of the list of objects, the cost of which for tax accounting is determined under } \\
\text { the cadastral registration data. The list includes garages, summer cottages, outbuildings, objects of } \\
\text { unfinished construction, etc. [1]. }\end{array}$ \\
\hline Pension reform in 2019 & $\begin{array}{l}\text { The pension system of the Russian Federation will have switched to a funded system by } 2028 \text {. But it } \\
\text { only makes the present situation hard. Russia, like many countries, faced with demographic problems. } \\
\text { There are more pensioners when the populations are aging and workforce is diminishing. } \\
\text { The contributions paid by working citizens are not enough, despite the fact that it is } 30.2 \% \text { of wages. } \\
\text { A further increase in the size of contributions is impossible, so the Administration chooses the path of } \\
\text { increasing the retirement age. As early as in the first half of } 2019 \text {, both men and women retired a little } \\
\text { later. After the end of the interim period, in 2028, men will retire at } 65 \text {, women will be } 63 \text {. }\end{array}$ \\
\hline Value added tax & $\begin{array}{l}\text { From January } 1,2019 \text { the base rate of value added tax increased from } 18 \text { to } 20 \% \text {. That directly } \\
\text { influenced the increase in the cost of the consumer basket of Russian households and virtually the } \\
\text { entire range of consumer and investment goods. [2]. }\end{array}$ \\
\hline
\end{tabular}

The majority of changes described above are specific. Namely, they have a clarifying nature and do not introduce any major changes in tax legislation. It should be noted that only a few of them are dramatic.

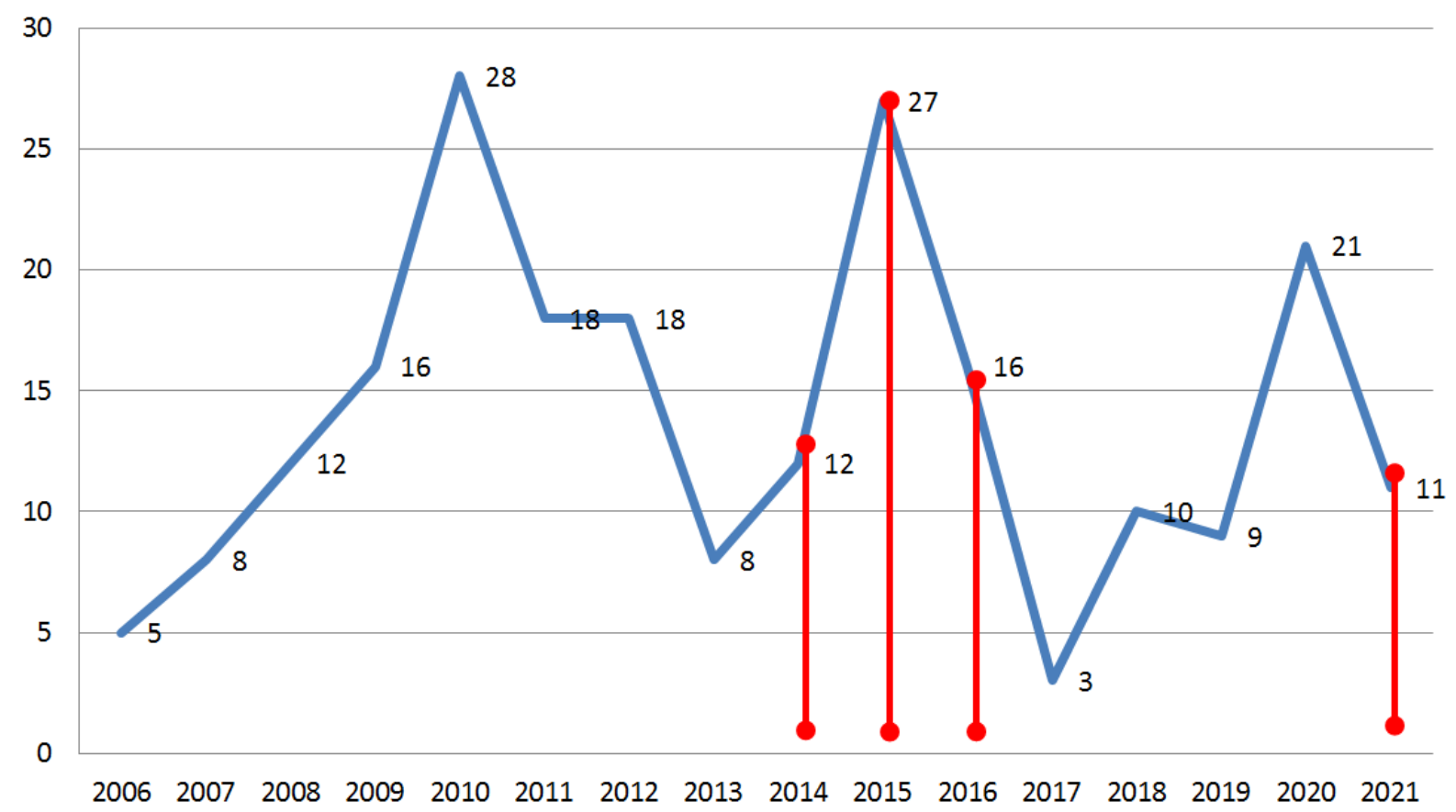

Figure 1. A dynamic of key tax changes in Russia. 
As seen from Fig.1, most cardinal changes distinctly took place after the crisis events of 2014. This turning point for the welfare of the Russian households could have triggered a strong response, such as avoiding a rational model of behavior.

The purpose of the study, therefore, is to search for behavioral features, deviations of Russian households' behavior in changing taxation. Section 2 reviews the relevant literature and discusses the proposed behavioral approach as a possible way of interpreting the reasons for a households' reaction. Section 3 provides a method of calculating the coefficients of elasticity of tax payments and demonstrates the need to apply the Pearson coefficient for the Russian context. The key hypothesis of the study is that households demonstrate varying degrees of reaction in changing tax legislation and seek to optimize the tax burden. Section 4 presents the dynamics of tax payments by the Russian households and discusses the results of calculations using the Pearson coefficient. Finally, section 5 provides the conclusion for the study with some key recommendations for public authorities to modernize tax policy.

\section{Literature Review}

Behavioral economics has been the focus of economists' attention since the 90s. And more importantly, in recent years academics and scientists have integrated and considered the behavioral aspects into their researches. Thanks to the intensive digitalization, economic links are complicated, and meanwhile, cognitive distortions in behavior of households are increasing. In particular, there are the studies of households' reaction to changes in tax legislation, aimed at identifying the behavioral characteristics of households. It may be supposed their greater exposure to behavioral distortions in tax matters.

Detailed consideration of the significant behavioral effects, the essence of which stated by authors of the largest studies, and our assumptions about how these effects can influence decision-making by taxpayers, namely households, are presented in Table 2 .

Table 2. Behavioral effects and their projected impact on tax policy

\begin{tabular}{|c|c|c|}
\hline effect & essence of the effect & expected impact \\
\hline $\begin{array}{l}\text { 1. Status quo and } \\
\text { rejection of } \\
\text { innovations }\end{array}$ & $\begin{array}{l}\text { Households tend to be neutral or completely postpone solving } \\
\text { problems with growth of volume and complexity of information } \\
\text { about their increases. This is expressed through resisting any } \\
\text { change and choice of foreknown options, even if the alternatives } \\
\text { may lead to better personal or collective results in financially or } \\
\text { materially benefits [3]. }\end{array}$ & $\begin{array}{l}\text { With regard to the sphere of household taxation, this } \\
\text { effect can manifest itself in several situations: (1) } \\
\text { unwillingness to learn information about new tax } \\
\text { benefits and to register them; (2) payment of sub- } \\
\text { optimal tax; (3) incorrect accounting of the tax base for } \\
\text { calculating the amount of taxes; (4) unwillingness to } \\
\text { optimize personal taxation. }\end{array}$ \\
\hline $\begin{array}{l}\text { 2. Achieving a } \\
\text { satisfactory but } \\
\text { sub-optimal } \\
\text { solution to the } \\
\text { problem. }\end{array}$ & $\begin{array}{l}\text { In conditions of too overloaded and complexity of information, } \\
\text { households tend to choose widely available alternative option } \\
\text { which minimally solves the problem. That being the case, there } \\
\text { is a deliberate denial of additional information processing for the } \\
\text { purpose of maximizing utility. Evidentially, in contrast to the } \\
\text { optimal way, households need more time and effort to make } \\
\text { financial decisions [4]. }\end{array}$ & $\begin{array}{l}\text { This effect implies that some actions taken to change } \\
\text { the terms of personal taxation by households are } \\
\text { suboptimal, for example, in situations of challenging } \\
\text { the size of the tax base through a court, issuing tax } \\
\text { deductions and refunds consisting of many payments, } \\
\text { imposing tax benefits. }\end{array}$ \\
\hline $\begin{array}{l}\text { 3. Uneven } \\
\text { perception of } \\
\text { losses and profits } \\
\text { with increasing } \\
\text { costs }\end{array}$ & $\begin{array}{l}\text { It may be named the multiplier effect giving rise to very } \\
\text { different types of risks that are focused on and assessed by } \\
\text { households. In this way, households usually overlook the } \\
\text { benefits concentrating on the risks, costs or losses associated } \\
\text { with changing their behavior. This deviation can be illustrated } \\
\text { the fact that households are usually ready to receive benefits } \\
\text { rather than pay. It is basically a matter of households perception } \\
\text { of losing when the futility of losing something much more than } \\
\text { the usefulness, in other words, they perceive negative emotions } \\
\text { from losses much more than positive ones from benefits [5]. }\end{array}$ & $\begin{array}{l}\text { This effect can be followed in situations of households' } \\
\text { income changes. For example, households with } \\
\text { increasing income pay attention to the amount of taxes } \\
\text { paid up to a certain point, while the possibility of } \\
\text { obtaining tax benefits and tax optimization is being } \\
\text { ignored. }\end{array}$ \\
\hline $\begin{array}{l}\text { 4. Temporal and } \\
\text { spatial } \\
\text { discounting. }\end{array}$ & $\begin{array}{l}\text { Households mainly are inclined to perceive things as less } \\
\text { valuable if they are further in time or space, even ignoring } \\
\text { benefits in the long run. People actually prefer smaller, but } \\
\text { quicker rewards to large rewards over time [6]. }\end{array}$ & $\begin{array}{l}\text { This effect is extremely important in taxation sphere as } \\
\text { there are not directly related taxes and social benefits; } \\
\text { many tax benefits or refunds obtained only after the } \\
\text { expiration of the tax period (quarter, half year, year), } \\
\text { which is a long time period for households; any long- } \\
\text { term interactions with tax authorities perceived as } \\
\text { ineffective and hopeless. } \\
\text { In addition, this effect can manifest itself in online and } \\
\text { offline interactions with tax authorities. For example, it } \\
\text { is much easier and more comfortable for households to } \\
\text { pay taxes online than to submit tax returns in person. } \\
\text { Interaction with the tax inspector by e-mail is } \\
\text { preferable to face-to-face meetings. }\end{array}$ \\
\hline $\begin{array}{l}5 \text {. Social } \\
\text { comparison and } \\
\text { adherence to } \\
\text { social norms }\end{array}$ & $\begin{array}{l}\text { Furthermore, being a part of society, households abide by the } \\
\text { certain formal and informal rules. People tend to make social } \\
\text { comparisons, watch the behavior of others, and conform to } \\
\text { social norms. Those explicit and implicit "rules," guidelines, or } \\
\text { behavioral expectations within a group or society establish } \\
\text { ethical economic principles considered normal or desirable [7]. }\end{array}$ & $\begin{array}{l}\text { This effect is of great importance for household } \\
\text { taxation. Consider that citizens see their friends, } \\
\text { acquaintances doing not pay taxes, and then they will } \\
\text { not be likely to pay themselves. In economies with a } \\
\text { weak system of administrative imposition, this effect } \\
\text { can lead to structural problems in the functioning of the } \\
\text { tax system. }\end{array}$ \\
\hline $\begin{array}{l}\text { 6. Fairness and } \\
\text { material } \\
\text { compensation as } \\
\text { intrinsic } \\
\text { motivators and } \\
\text { extrinsic } \\
\text { motivators }\end{array}$ & $\begin{array}{l}\text { In general, larger incentives or disincentives lead to stronger } \\
\text { behavioral responses. However, the effects of financial } \\
\text { incentives are often surprisingly short-lived and inconsistent. } \\
\text { Households may even react negatively to external rewards (for } \\
\text { example, by demonstrating a loss of motivation), especially if } \\
\text { the intrinsic motivation for the target behavior is high [8]. }\end{array}$ & $\begin{array}{l}\text { This uncommon effect can be observed in cases of } \\
\text { specific taxation of households related to charity, } \\
\text { support for the needy, and environmental protection. } \\
\text { For example, refunds from such transactions can be } \\
\text { perceived negatively and reduce further motivation. }\end{array}$ \\
\hline
\end{tabular}


The field of taxation is of particular interest to researchers concerned with behavioral theory. The payment of taxes by households is an irrational activity as far as opportunity costs. Indeed, there is a significant gap between the amounts paid and the social benefits received. In this situation a social contract and measures of state coercion keep the tax system in a stable state. In some Latin American or African countries there is a vicious circle, when households do not pay taxes because of a level loss of social benefits, and consequently social services do not develop. As a result, it is important to apply the effects of behavioral finance in order to correct the reaction of taxpayers to changes in tax legislation.

In this part of our article, the main studies on the households' tax behavior, divided into several groups, are presented.

\section{Assessment of the households' reaction to changes in tax legislation by calculating the elasticity of tax receipts from the rate. Mathematical modeling of behavioral features in tax area}

The important scientific work relates to scientific observations in income tax in the United States. "Essays on Behavioral Responses to Taxation" by Robert Andrew Whitten [9] is devoted to a correlation between income and changes in marginal tax rates. By measuring the degree to which taxpayers' bunch at kink points, the author explores "bunching" at US income tax kinks. According to the results of his study, the reaction cannot always be equal, and most kinks do not generate statistically noticeable bunching responses. In addition, the scientist indicates that significant changes in taxation do not always cause a strong response. The main impetus for studying behavioral responses in tax area is the search of better tax policy and optimal taxation.

Much attention is given to the 1986 Tax Reform Act and its implications on households. This document explored by Gerald Auten and Robert Carroll is a natural experiment caused income inequality. [10]. The authors examine the roles of taxes and various non-tax factors significantly affecting households. For example, mathematical models show that a line of work does not affect taxation. According to the author, the key influence is the rate, which considerably changes behavior of taxpayers. It is also established that during the late 1980s growth of relative income relates to behavioral responses to the tax changes.

The research on inheritance tax statistics by David Julfayan [11] gives a detailed description of estate taxation affecting bequests. The study is conducted on the basis of time series data from federal estate tax revenues. It is shown that using property tax and inheritance tax taxpayers estimates the expected rate of return differently in similar situations. The scientist proves that Taxes on capital may have influence on saving decisions by reducing rates of return. Meanwhile, households in operating transactions with insecurities focus on the financial result. The main author's idea about savings is that the effects of the estate tax depend on the preferences of the potential saver.

Nigar Hashimzadeh et al. [12] gave valuable information about the theory of expected utility making it applicable to behavior of taxpayers. Scientists developed the ideas and formulated the foundations of a mathematical model that had to modernize approaches to assessing tax evasion. They drew our attention to several models depending on alternative households' behaviors.

\section{Assessment of households' responses to various types of tax concessions.}

In the study "Tax measures and household financial behavior: Evidence from France”, Christophe Schalck [13] examines investment behavior of households in France and posits tax measures. A relationship between the tax impact on the determinated instrument and investment preferences in others reveals a significant effect on the investment behavior of households.

Additionally, by examining households' incentives and decisions about investment in trading assets, James M. Poterba [14] systematizes the views of scientists on the structure of households' portfolios and risk-taking of portfolio choice. Special attention is given to the investor behavior, behavior of mutual funds is found to be of great interest, as well. A thorough analysis is made of cases of a systematic effect on the nature of risk taking and the structure of households' investment portfolios.

Nada Eissa et al. [15] evaluate influence of the labor supply on the Earned Income Tax Credit. The authors generate that indeed there is a strong relationship between the provision of tax credits and the supply of labor. Households are actively responding to tax breaks, which directly affect their income. This interaction has particular relevance to groups of the population with low or lower middle income.

\section{Empirical studies aimed at addressing households' tax behavior by using the behavioral effects.}

Specialists from the Office of the Chief Economic Adviser (OCEA) in the Scottish government presented a large study in 2020, the purpose of which was to identify the features of behavioral taxation in Scotland. The study provides an extensive overview of theoretical developments in this area. This paper shows that there are the marginal tax rates which can be raised without sacrificing economic growth. Besides, behavioral responses to changes in tax policy, for example the mobility response, are more significant when there is a tipping point. Due to the limited empirical data, not all theoretical models designed by specialists have been realized. The full extent of results has been demonstrated that taxpayers with low and medium taxes are not adapted to changing tax rates [16]. 
The analytical report of the Department of Finance An Roinn Airgeadais from Ireland made a significant contribution to the development of the topic of a correlation between households and changing tax policy. Using an extensive descriptive base, specialists of the department examined the influence of behavioral economics on households' tax behavior within the framework of 4 fundamental models: salience; bounded rationality; reference dependence and loss aversion; time inconsistency [17].

Stewart Kettle et al. "Behavioral Interventions in Tax Compliance" [18] demonstrated and analyzed in detail the features of the existing practice of using behavioral effects to increase tax revenue in Guatemala. Using a simple method of mailing tax notifications by mail, the effects of the status quo and joining a social group reveal. In addition, this example shows that behavioral effects can be used to manage households' payments. And remarkably, the experiment brought additional income to the budget.

William J. Congdon et al. [19] discuss the implementation of tax policy in the transformation context of behavioral economy. The authors criticize the traditional approach, in which the response to taxation is assessed in terms of the elasticity of tax contributions. The US income tax and various tax incentive programs were collected as a data material for this research.

Michal Greenstein-Weiss et al. [20] performed a largescale experiment using behavioral effects. Taxpayers, who decided to return tax funds online, were divided into 2 groups $-25 \%$ and $75 \%$. The first group received several options of motivational materials to make different saving. The second group did not receive any materials. Analysis of findings showed that such a simple method of informational impact would be an effective tool and a measure in the field of state regulation of economic policy in the country.

The report of the Inter-American Development Bank, composed by Nina Rapoport et al. [21], is about the experience of solving public administration issues in Latin American countries by the effective application of the behavioral approach. The report addresses a variety of issues: energy conservation and transport system management, employment, public expenditure efficiency, and taxation. The methods of increased awareness of tax incentives: changed tax notifications and the use of new channels of interaction, tax lotteries - help to regulate the tax behavior of households and have the positive effect in terms of tax collection.

Rajeev Cherukupalli [22] in his article examines the economic aspects of tobacco smoking and related behavioral characteristics. He concludes that tobacco smoking provides many opportunity costs in other significant social areas nationwide. Therefore, it is important to design and implement more complex tax systems, associated behavioral characteristics.

All scholars agree that the state policy in taxation needs to be modernized in accordance with the behavioral characteristics of households. Studies show that integration of the basic effects of behavioral finance allows achieving growth of tax payments. Indeed, the search, development and substantiation of this topic can assist in resolving large-scale economic crises and reforming the tax system. However, we draw the attention that the largest studies do not pay attention to specific behavioral effects characteristic exclusively for the sphere of taxation.

In this regard, it is of particular interest to consider the provisions of the behavioral theory for interpretation the nature of the reaction of households to changes in taxation.

The above positions of the authors show that the method of calculating the elasticity of tax payments is more frequently used in determining the reaction of households to changes in taxation. This approach allows unequivocally revealing any reaction relationship; however, this requires a significant statistical base. Therefore, almost every scientist stops at establishing the presence of reactions avoiding tryings of explication the strength of the reaction or their reasons. That is the serious disadvantage, which we try to address by using the Pearson Correlation Coefficient for calculations in section 4.

\section{Methods and Methodology}

In the scientific community to date there is a consensus regarding the methodology for studying the reaction of taxpayers to changes in tax legislation. The main method is to calculate the elasticity of tax payments depending on changes in taxation conditions. The main idea of this simple method relies on the measurement of a percentage change of tax payments in response to a change in tax benefits, deductions and other tax changes. After it results can be used to make management decisions regarding taxation.

In academia, many scientists apply this method with some success to estimate for Taxable Income with respect to Marginal Tax Rates [23], Corporate Taxation [24], Property Tax [25], Individual Income Tax and Economic Growth [26] etc.

This method has some significant advantages and disadvantages by comparison with other methods (see Table 3). 
Table 3. Advantages and disadvantages of calculating tax elasticity

\begin{tabular}{|c|c|}
\hline advantages & disadvantages \\
\hline $\begin{array}{c}\text { Universality of elasticity. } \\
\text { It can be applied a wide range of indicators for calculations - tax } \\
\text { revenue, tax refunds, tax benefits, tax rates, etc. }\end{array}$ & $\begin{array}{c}\text { The complicated calculation with an unchanged tax system. Under } \\
\text { constant conditions, it is necessary to differentiate the data. }\end{array}$ \\
\hline $\begin{array}{c}\text { The objective character of the method. } \\
\text { It is based on fundamental concepts of economic theory and can } \\
\text { be applied with minimal assumptions. }\end{array}$ & $\begin{array}{c}\text { An extensive statistical base is required for calculating elasticity. } \\
\text { Furthermore, a special request to the tax authorities is required to } \\
\text { obtain detailed statistics, because the majority of data cannot be } \\
\text { made publicly available. }\end{array}$ \\
\hline $\begin{array}{c}\text { Ease of mathematical calculation. } \\
\text { It does not require special knowledge or computing equipment. }\end{array}$ & $\begin{array}{c}\text { The need for constant calculation of elasticity. Due to the constant } \\
\text { and quick reaction of taxpayers to changes in tax legislation, it is } \\
\text { important to constantly update and recalculate the coefficients. }\end{array}$ \\
\hline $\begin{array}{c}\text { Possibility of modeling. } \\
\text { Elasticity coefficients can be the basis for constructing } \\
\text { multivariate taxation models. }\end{array}$ & \\
\hline $\begin{array}{c}\text { Practical significance in the public administration. } \\
\text { Elasticity coefficients can indicate positive or negative changes in } \\
\text { taxation. }\end{array}$ & \\
\hline
\end{tabular}

In Russia, tax statistics by the Federal Tax Service mainly comprise indicators of tax payments, tax violations from the national level and in the regions. Unfortunately, a deeper analysis on the data of official statistics is not possible to conduct because of the lack of data on differentiation among taxpayers, for example, by an income level, a professional activity, an educational level. In addition, in the Russian household taxation since 2006 there have been many changes practically not affecting the main indicator for calculating the elasticity — the tax rate. Hence, the only option for calculating the elasticity could be either the calculation of the total tax burden of households, or the calculation of a representative tax rate for households, that is topic of a separate study in our view.

Within the framework of this study we assess the response of households in a different way - by calculating the correlation coefficients between indicators of household payments to the budget, the number of changes in tax legislation and objective indicators of household income.

This method is usually used by scientists to find relationships between the financial behavior of households with other aspects of tax area, for instance: the study on Household Debt and the Dynamic Effects of Income Tax Changes [27]; the study on the Impact of Corporate Taxes on Employment and Income [28]; the study on Tax Reform and Interstate Migration [29]; the study on Tax Changes on Consumer Spending [30].

To assess the correlations, we will use the standard Pearson Correlation Coefficient Equation. By the Pearson product-moment correlation one must first determine the covariance of the two variables in question. Next, one must calculate each variable's standard deviation. The correlation coefficient is determined by dividing the covariance by the product of the two variables' standard deviations [31].

$$
P_{x y}=\operatorname{Cov}(x, y) / \sigma_{x} \sigma_{y}
$$

where:

$\mathrm{P}_{\mathrm{xy}}=$ Pearson product-moment correlation coefficient

$\operatorname{Cov}(\mathrm{x}, \mathrm{y})=$ covariance of variables $\mathrm{x}$ and $\mathrm{y}$

$\sigma_{\mathrm{x}}=$ standard deviation of $\mathrm{x}$

$\sigma_{\mathrm{y}}=$ standard deviation of $\mathrm{y}$

According to the standard values of the Chaddock scale [32] we assess the tightness of the connection between the sets (Table 4).

Table 4. Chaddock scale

\begin{tabular}{|c|c|c|c|c|c|}
\hline $\begin{array}{c}\text { correlation } \\
\text { coefficient }\end{array}$ & $0,1-0,3$ & $0,3-0,5$ & $0,5-0,7$ & $0,7-0,9$ & $0,9-0,99$ \\
\hline connection & low & moderate & growing & high & very high \\
\hline
\end{tabular}

Using Fisher's F-criterion we compare the actual obtained value with the tabular one and check the constructed models.

$$
\mathrm{F}=\left(\mathrm{R}^{2} / 1-\mathrm{R}^{2}\right) *((\mathrm{n}-\mathrm{m}-1) / \mathrm{m})
$$

$\mathrm{m}$ - number of factors in the model

$\mathrm{R}^{2}$ - the coefficient of determination

In Excel using a function with a degree of freedom of 1 and a probability of rejecting the hypothesis of 0.05 we determine the tabular value of Fisher's F-test. If the actual value of the F-criterion is greater than the tabular value, the conclusion is made about the statistical significance of the dependence [33].

Thus, in the next section we choose economic indicators for identifying the relationship, which proves whether households try to optimize their tax burden and get more tax breaks as they change or tighten the tax policy.

\section{Results}

The reaction of households to changes in tax legislation is evident in data on the payment of taxes from 01.01.2013 to 01.06.2021. 
In the first part of the study, we described this time interval as the period of the most expected striking reaction of households to changes in tax legislation. The systematized statistical information of this period shows some logical and adequate reactions of households and, in contrast, the absence or the implicit nature of reaction. It directly indicates a lack of households' susceptibility to tax changes and their irrational financial behavior.

The prepared sample includes 2 different sets: (1) a small sample of annual indicators between 2013 and 2020;
(2) monthly data on the amount of paid and accrued land tax, property tax of individuals, and transport tax in the period from 01.01.2013 to 01.06.2021.

Figure 2 presents a brief summary of changes in the value of each of the taxes between 2013 and 2020 .

The dynamics of each tax must be illustrated separately. On the one hand, the total level of payments by individuals in the period under review grew, on the other hand, each of the taxes showed an ambiguous trend.

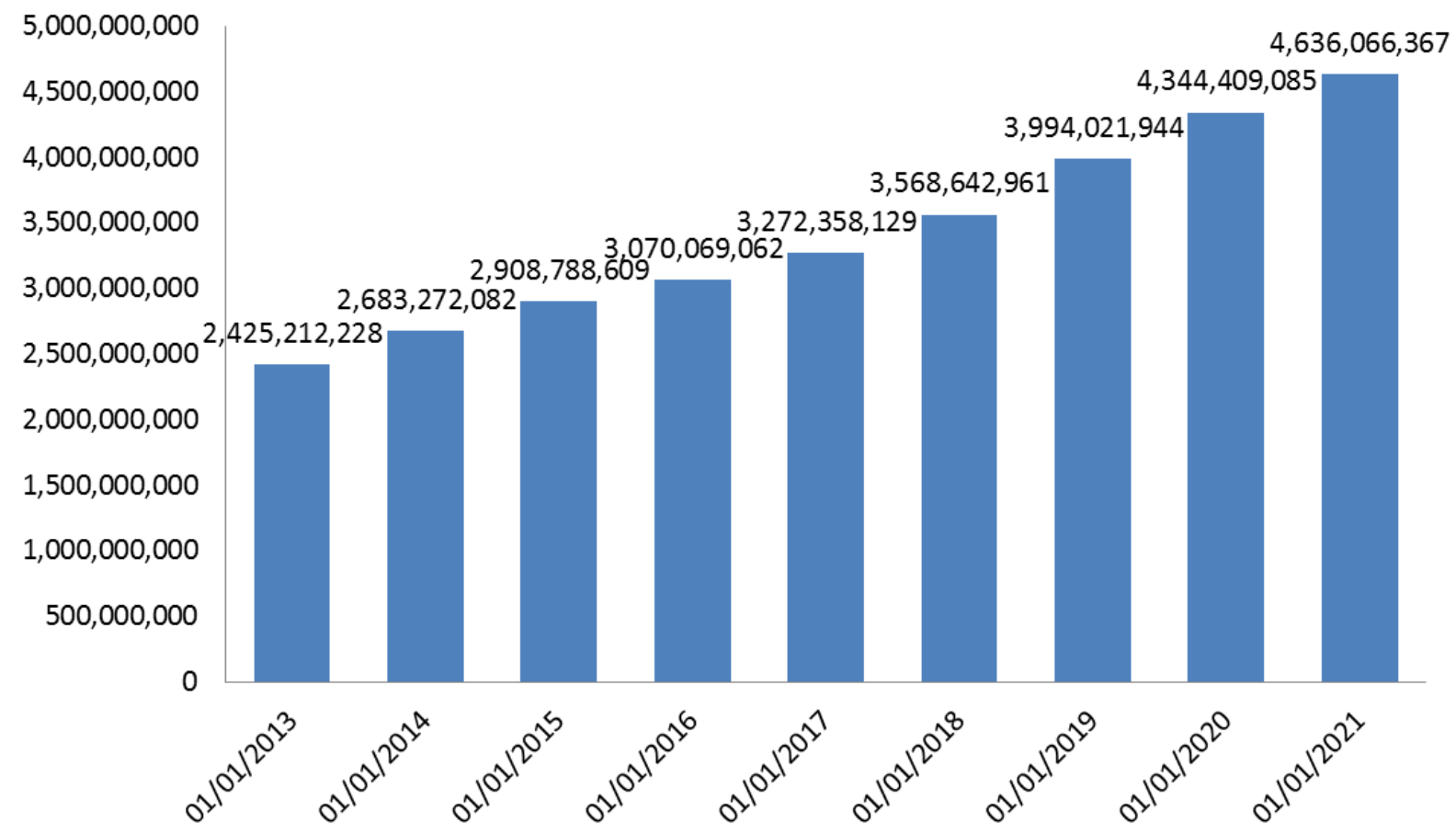

Figure 2. The total amount of payments for income tax, property tax, land and transport tax of individuals in 2013-2020, thousand rubles

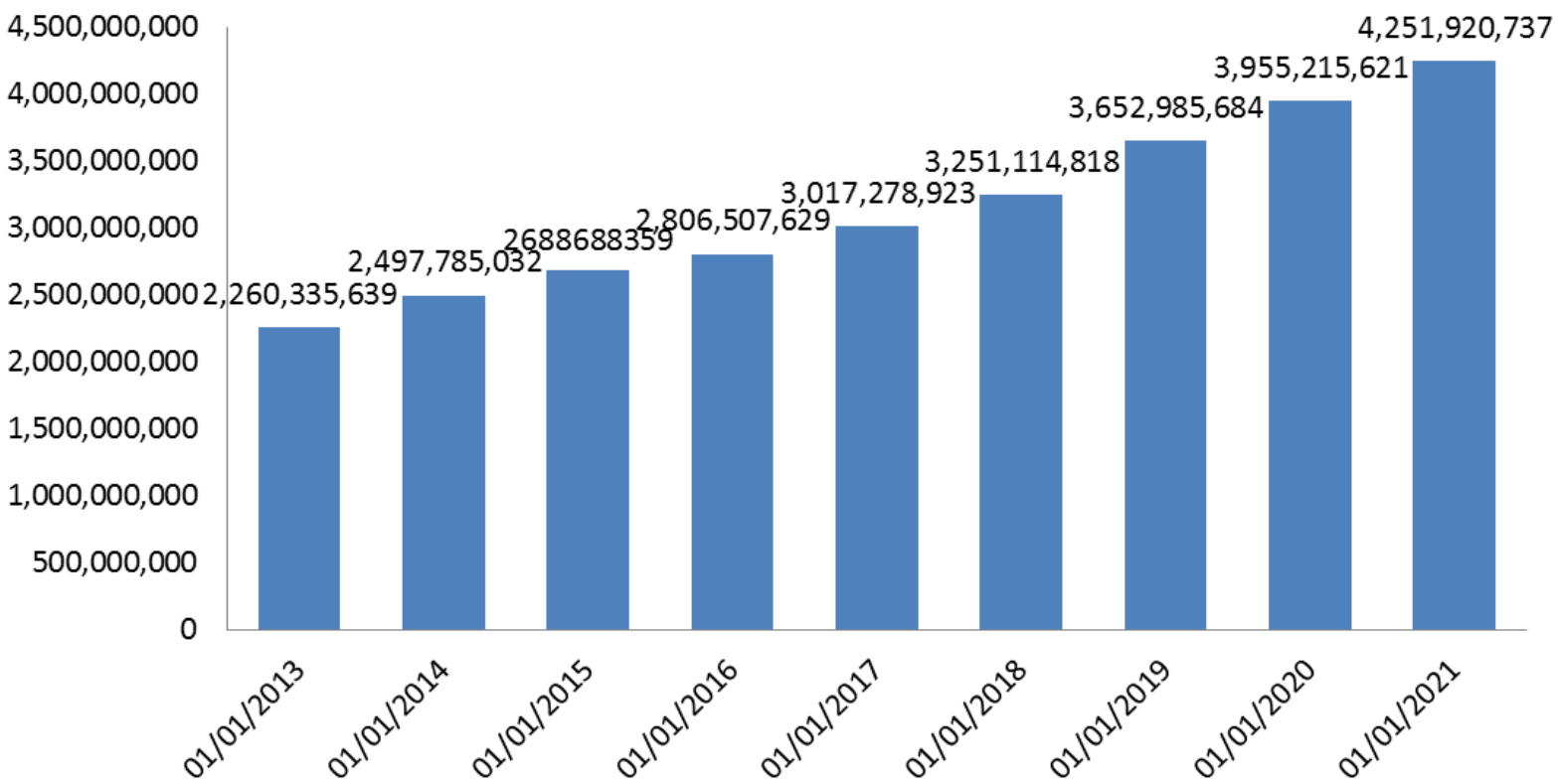

Figure 3. The amount of personal income tax paid by a tax agent-employer payment in 2013-2020, thousand rubles 


\section{Personal income tax paid by a tax agent-employer}

Below is a graph of changes in the amount of personal income tax paid by employers-tax agents (Figure 3).

The feature of this tax is that households practically cannot influence their value; accordingly, it is paid by the withholding agent-employer. The only option for influence is through the use of standard, social tax deductions.

The amount of this tax has an almost full direct correlation with the dynamics of the amount of salaries. Consequently, it is almost impossible to find any correlation with other economic indicators.

\section{Personal income tax paid for additional income of individuals}

In many cases this tax is related to taxes on rent or sale of real estate, winnings in contests and lotteries, bank deposits with an increased rate, etc. The obligation to pay this tax is imposed on taxpayers, for this reason, the poor fiscal discipline may be expected regarding these amounts [34]. There are the amounts of personal income tax payment for certain types of income (Figure 4).

Indeed, now it is possible to observe not so obvious dynamics of tax payments, indicating different patterns of tax behavior.

\section{Personal property tax}

In fact, citizens of the Russian Federation do not keep track of the cadastral value of their property. They find out only at the moment of receiving the tax return or during challenge its value in court, as practice shows [35]. Figure 5 presents the amount of property tax paid by individuals.

The amount of payments under this tax can be significantly influenced by tax deductions and refunds, which application degree directly indicates the reaction of households to changes in tax legislation.

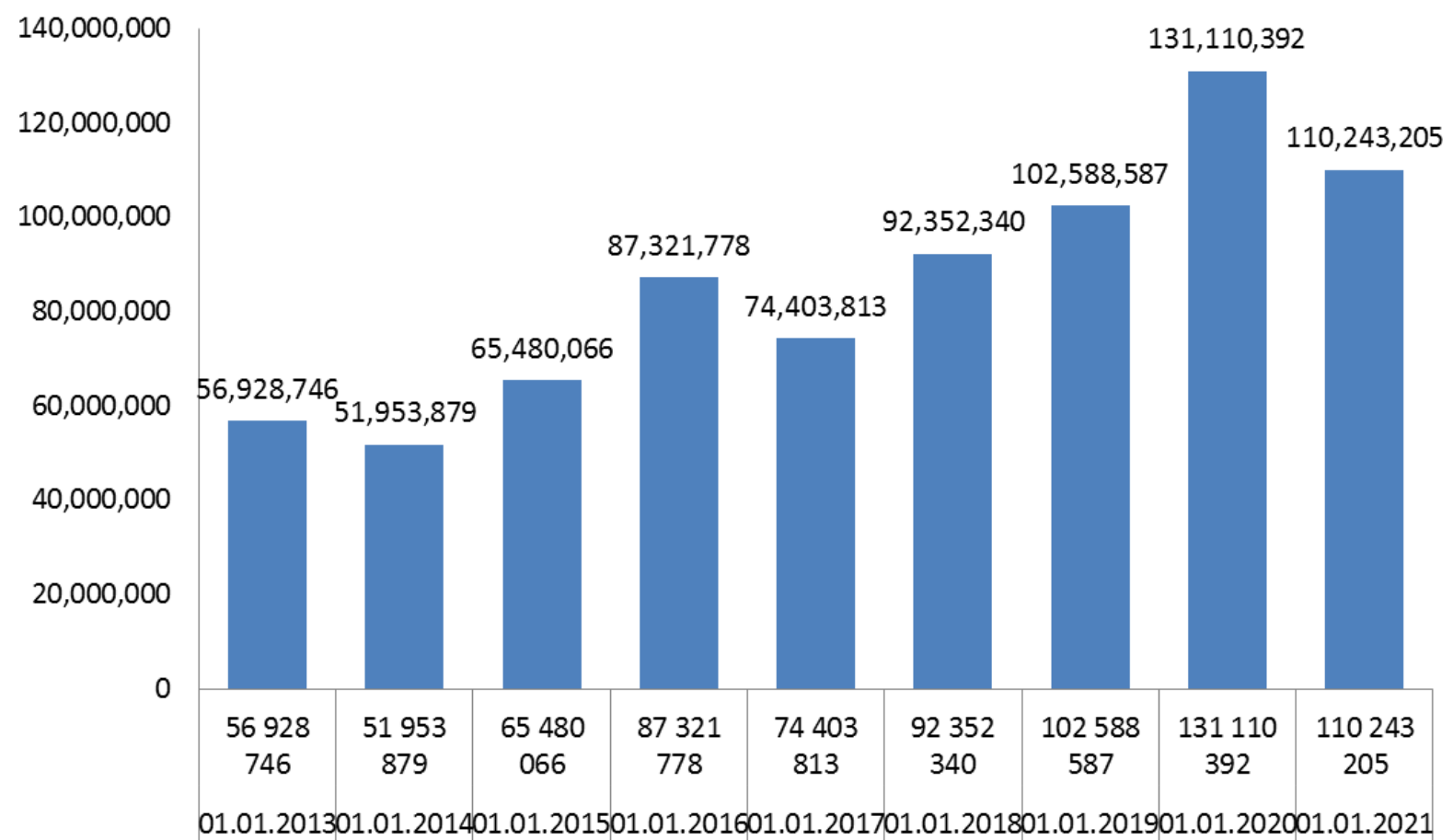

Figure 4. The amount of personal income tax payment for certain types of income in 2013-2020, thousand rubles 


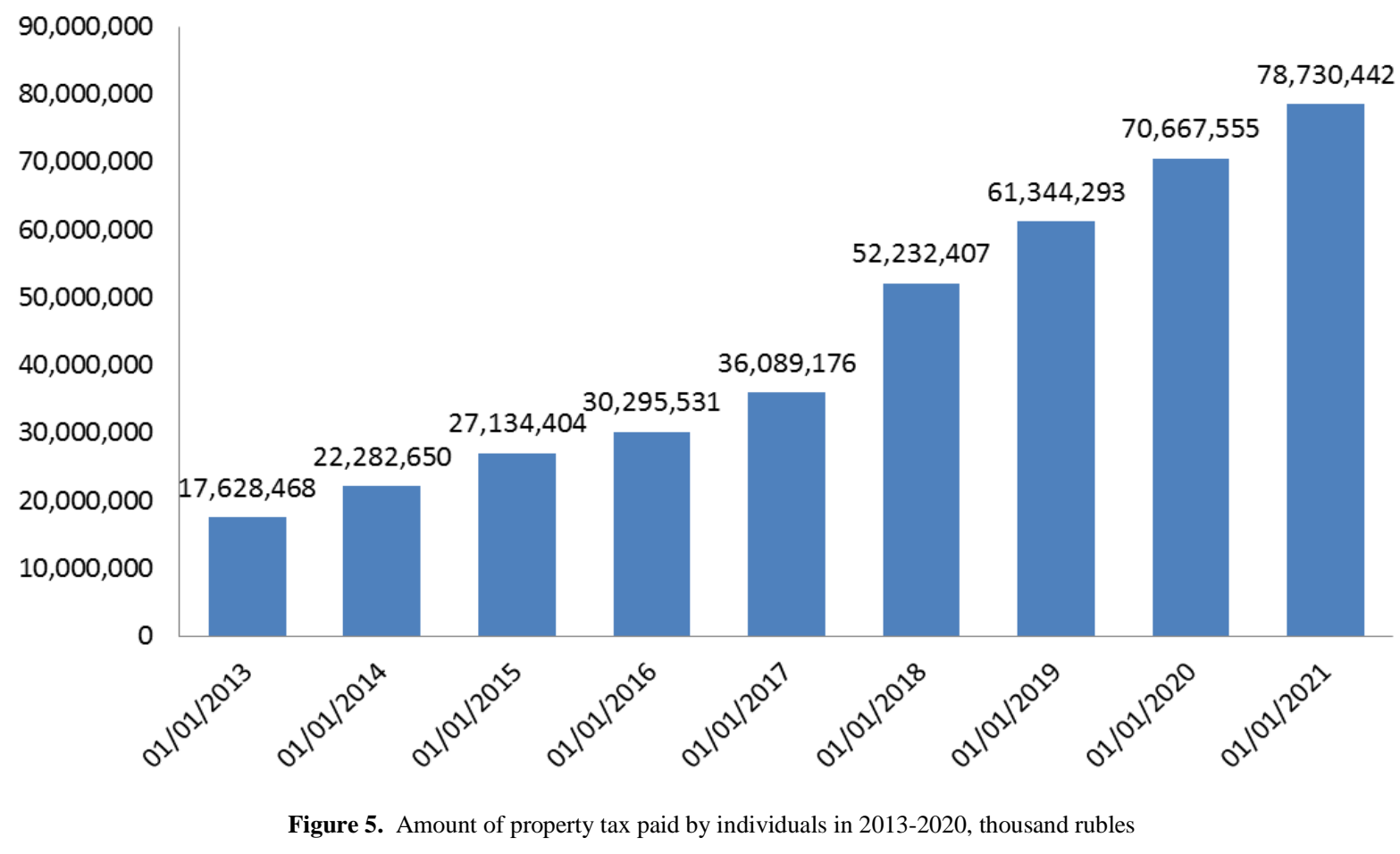

\section{Land tax of individuals}

Below is the amount of land tax from individuals (Figure 6).

According to the economic essence and the system of administration, this tax should repeat the dynamics of the tax on property of individuals. However, the changes in tax legislation have clearly affected its dynamics by making it multidirectional.

\section{Transport tax for individuals}

The following is the amount of paid transport tax payments of individuals (Figure 7).

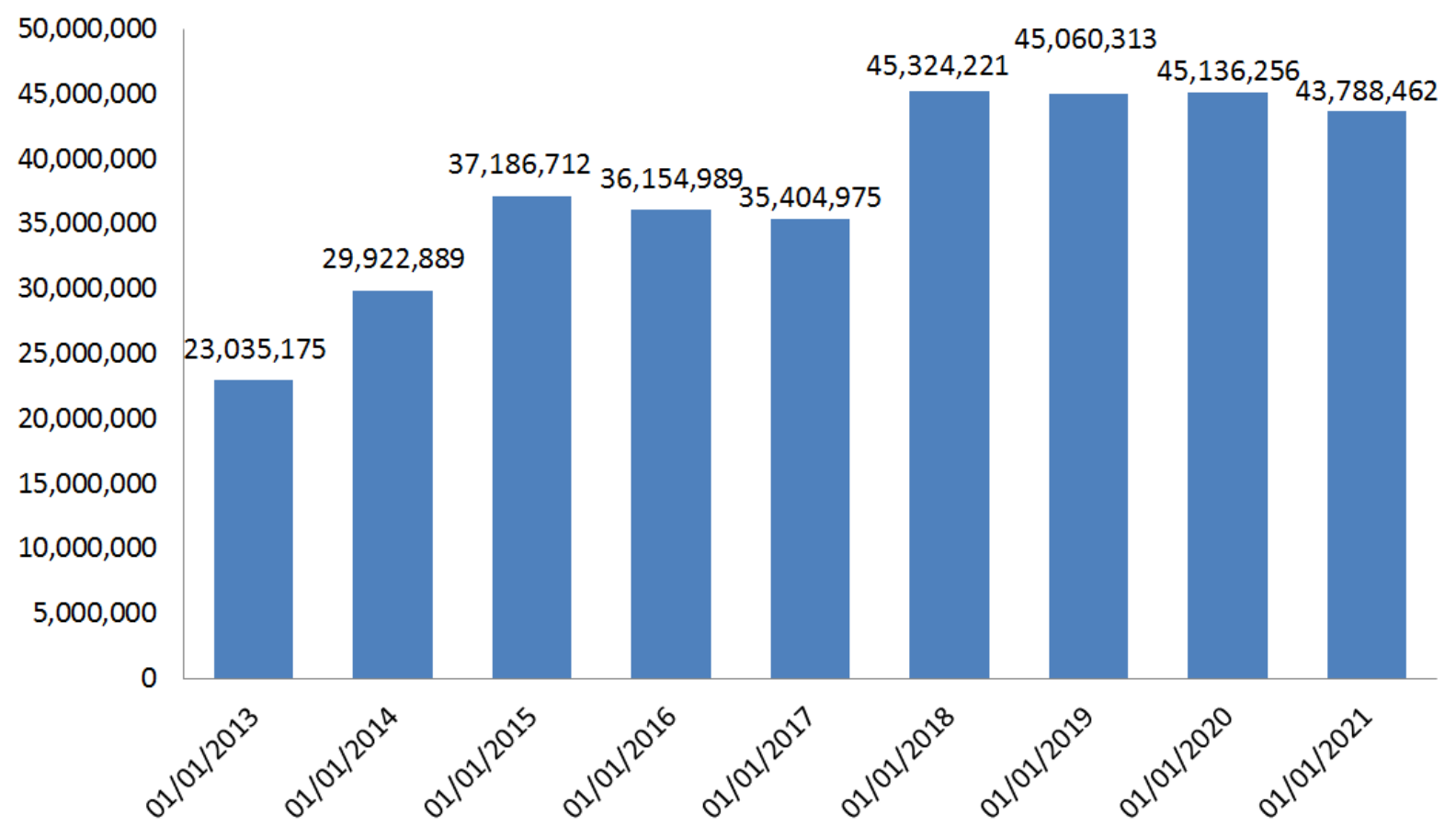

Figure 6. Land tax of individuals in 2013-2020, thousand rubles 


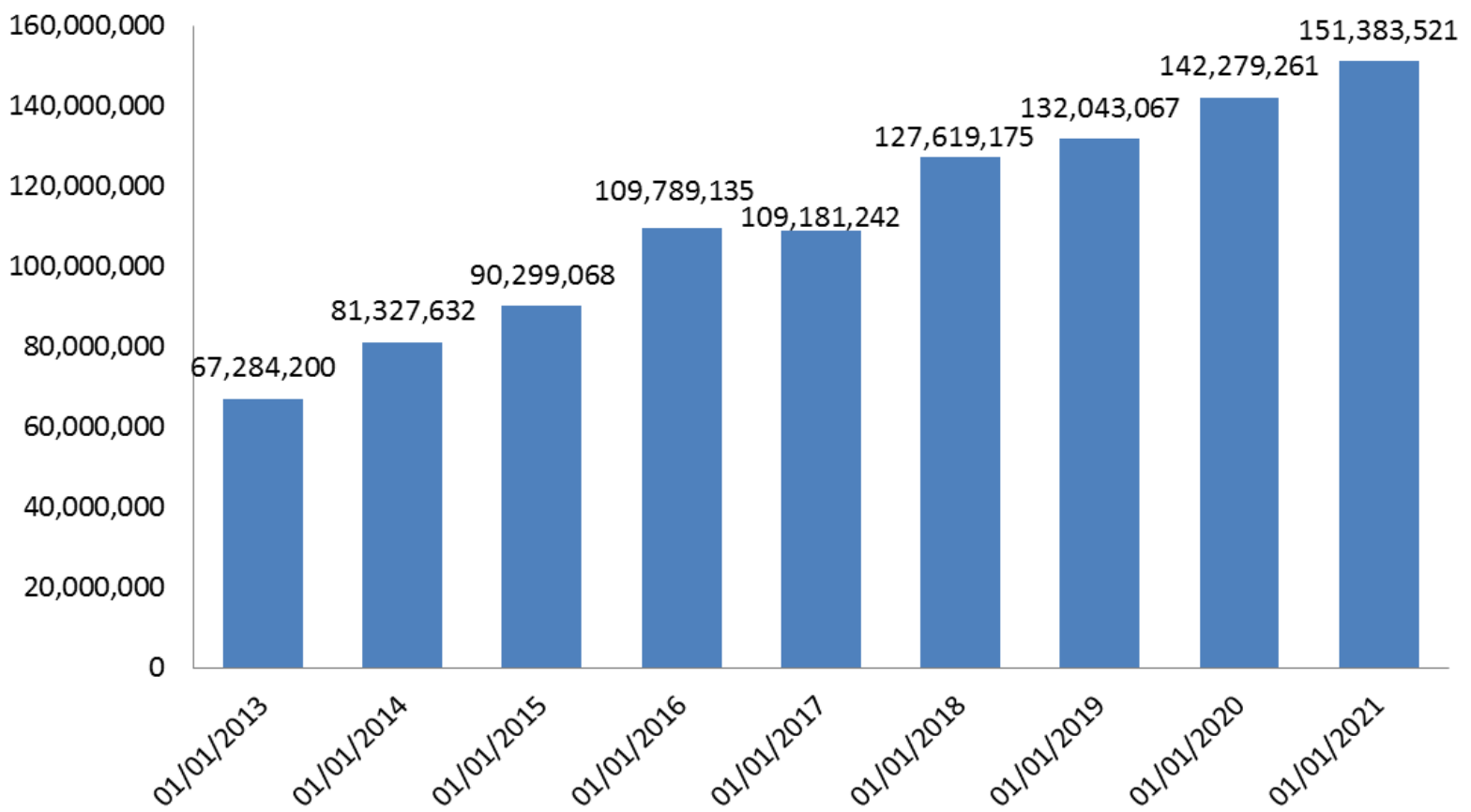

Figure 7. Transport tax for individuals in 2013-2020, thousand rubles

In the Russian Federation, this tax is an unusual for the calculation as based on engine power of the car. A number of benefits, meanwhile, are provided that reduce the tax base.

In that regard, choosing indicators for calculations requires a more in-depth examination. It is especially important to consider the issue of priority of household tax payments.

Households first satisfy their current needs, taking into account a rational model of behavior, such as the purchase of food, utility costs, communications expenditure, transport charge, etc. And only last they pay tax payments. This is dictated by the gap in perception of payments and obtaining of social services.

In addition, objective factors as time to pay bills can also affect the nature of household tax payments. In the Russian Federation, tax on individuals, land tax and transport tax are paid at the end of the year, until December 1. At the same time, tax declarations begin to come in August-September by mail or through the information state portal "Gosuslugi". Personal income tax paid on salaries is calculated and paid monthly by the employer-tax agent, and personal income tax for additional income of individuals is paid until July 15.
According to this understanding of tax dynamics, we distinguish several aspects that affect the nature of household tax payments:

\section{Subjective perception of the received social benefits}

For instance, if people feel improvements of communal or road facilities, or the level of social security during the year, they are most likely to pay willingly any amount of taxes. In turn, the State to fulfill its functions affects the quality of life of households. For a comprehensive measurement of the quality of household's life, we use the "Quality of Life Index by Country" [36]. The index value is shown in figure 8.

Using a small ineffectual sample to assess the relationship is due to the absence of a monthly indication of this index. The second indicator is the total amount of all taxes paid by households in the Russian Federation between 2013 and 2020 (see Table 5).

The calculation data show that in the period under review there is a strong relationship between the standard of living and the amount of taxes paid. In other words, households tend to pay more taxes as their quality of life improves. 


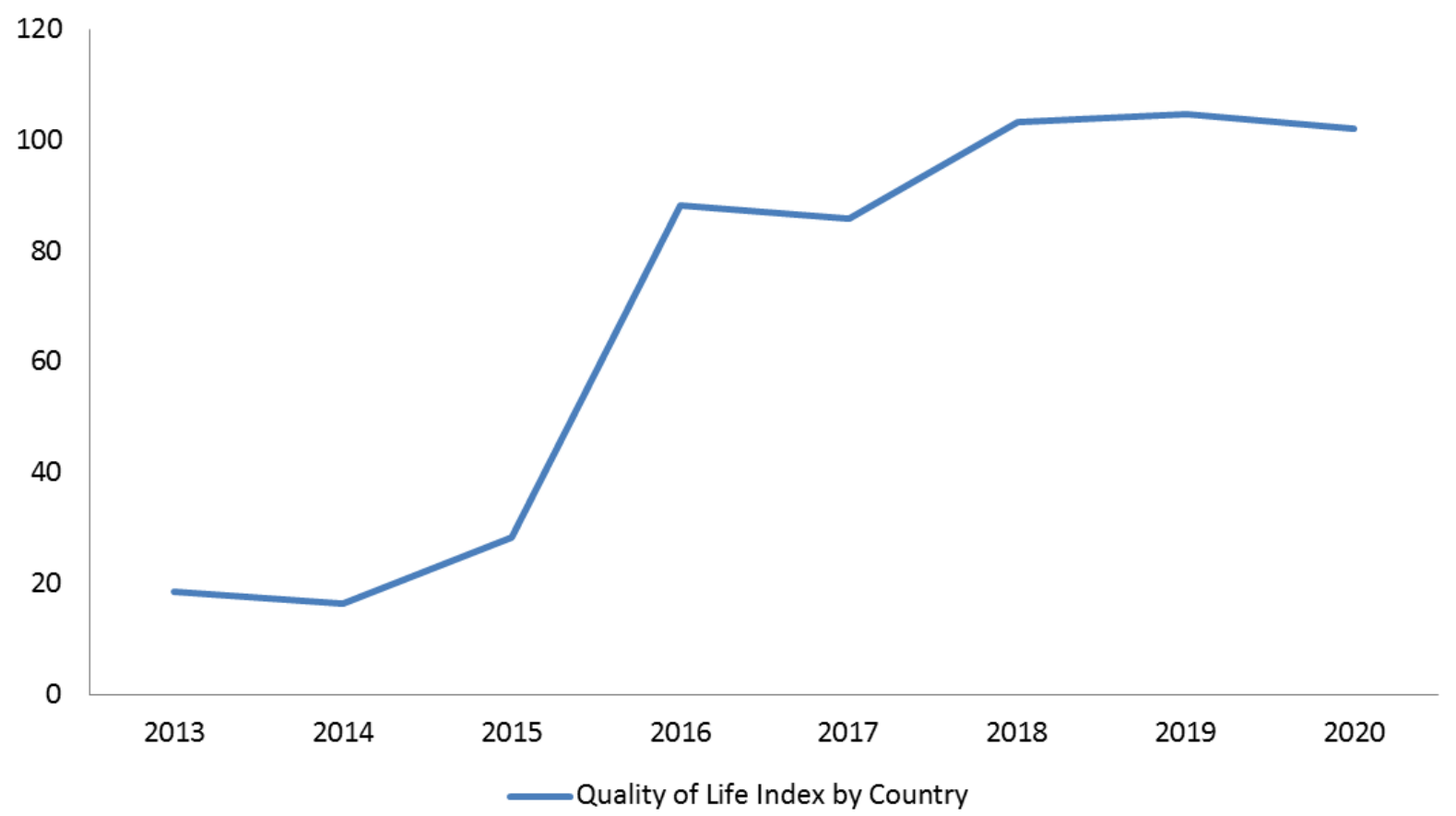

Figure 8. Quality of Life Index by Country in the Russian Federation, 2013 - 2020

Table 5. Relationship assessment between total amount of all taxes paid by households and Quality of Life Index by Country, 2013 - 2020

\begin{tabular}{|c|c|c|c|c|c|}
\hline $\begin{array}{c}\text { Pearson } \\
\text { coefficient }\end{array}$ & $\begin{array}{c}\text { Communication } \\
\text { tightness on the } \\
\text { Chaddock scale }\end{array}$ & $\mathbf{R}^{2}$ & $\begin{array}{c}\text { Actual F- } \\
\text { score }\end{array}$ & $\begin{array}{c}\text { F-test table } \\
\text { value }\end{array}$ & Output \\
\hline & high & $\begin{array}{c}0,73001935 \\
8\end{array}$ & 16,2238156 & $\begin{array}{c}5,98737758 \\
4\end{array}$ & $\begin{array}{c}\text { The actual value of the F-criterion is } \\
\text { greater than the tabular one, the } \\
\text { coefficient of determination is statistically } \\
\text { significant }\end{array}$ \\
\hline
\end{tabular}

\section{Household cash income}

Rosstat presents data on the distribution of households by income level, but does not correlate this data with the amount of taxes paid. Hence, we take the sum of all cash income except income from business and salaries to examine the tendency of households to optimize their taxation as income rises (Figure 9). The amounts of tax payments are used without personal income tax [37], as the common macroeconomic data is made available for all types of households' cash income.

In addition, this data presented exclusively in nominal terms does not have a monthly detail.

As seen from the table 6, the dependence of these values is almost linear, to wit, households make minimum efforts to optimize their taxation.

\section{A system of salaries.}

The key source of income for the Russian households is salary; in 2020, this is $58 \%$ of total cash income. The value of the average annual nominal salary is shown in figure 10 .

For calculating this indicator the dynamics of real salaries can only be relative, as during this period Rosstat changed methodology more than once.

The availability of a high connection is absolutely natural, as the amount of the tax paid is a derivative of the nominal salaries (Table 7). However, the expected absolute functional connection is absent, which indicates households' tendency to use tax breaks and although optimize personal taxation the least.

Table 8 presents the relationship between nominal salaries and other types of income, taxed on personal income in accordance with Article 228 of the Tax Code of the Russian Federation.

In fact, the expected moderate or weak relationship should be between these indicators, but the data shows the completely unrelated the sets. In other words, households are not inclined to associate the payment of the corresponding tax payments with salaries.

In all the taxes under consideration (Table 9, 10, 11), we see little or no correlation, which indicates that households are reluctant to pay taxes from salaries. It can be assumed that households link the source of income and the corresponding type of tax paid. 


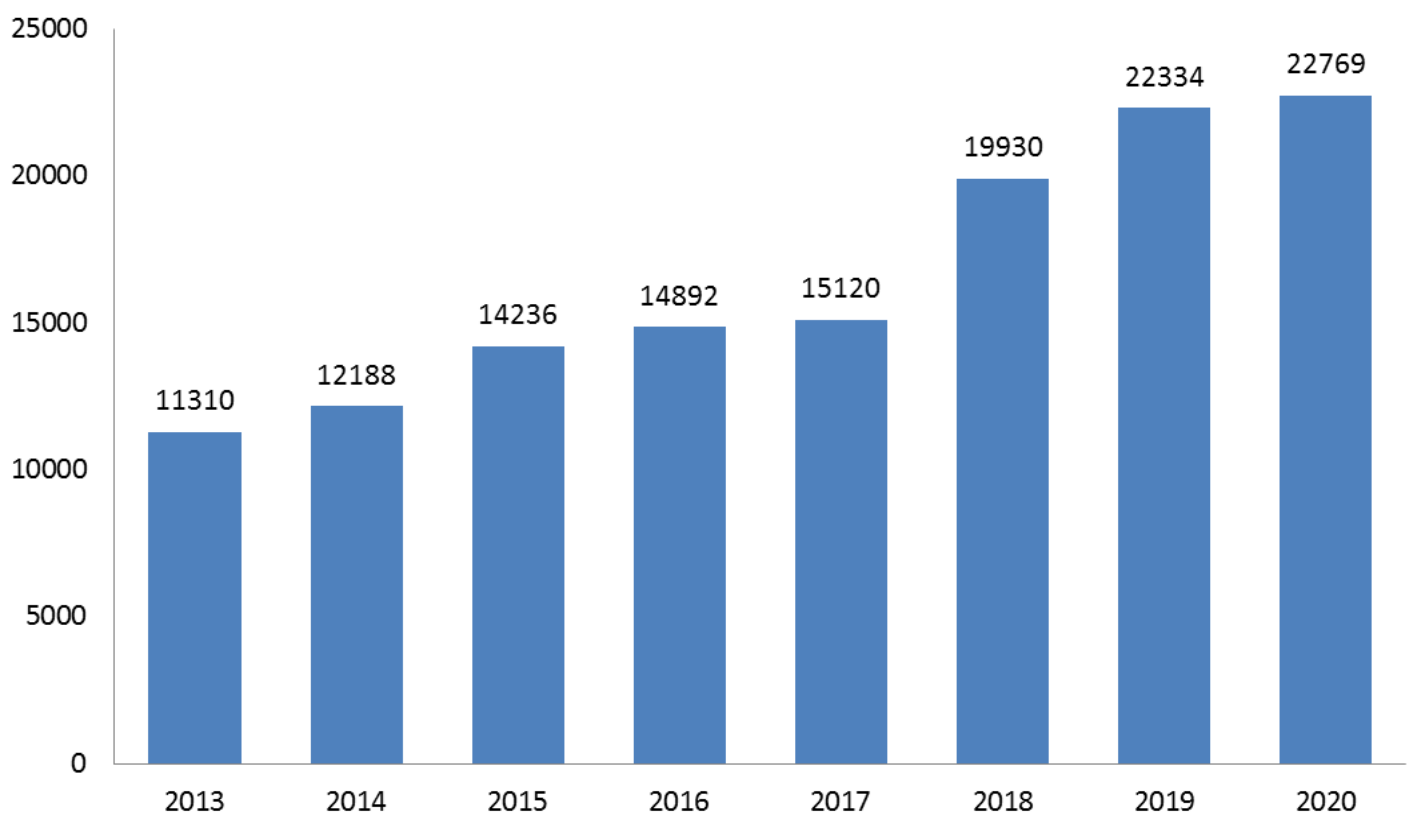

Figure 9. Total cash income of the Russian households except income from an entrepreneurial activity and salaries in 2013-2020, billion rubles

Table 6. Relationship assessment between total cash income of the Russian households and amount of taxes paid, 2013 - 2020

\begin{tabular}{|c|c|c|c|c|c|}
\hline $\begin{array}{c}\text { Pearson } \\
\text { coefficient }\end{array}$ & $\begin{array}{c}\text { Communication } \\
\text { tightness on the } \\
\text { Chaddock scale }\end{array}$ & $\mathbf{R}^{2}$ & $\begin{array}{c}\text { Actual F- } \\
\text { score }\end{array}$ & $\begin{array}{c}\text { F-test table } \\
\text { value }\end{array}$ & Output \\
\hline 0,976695155 & very high & 0,953933426 & 124,2462813 & 5,987377584 & $\begin{array}{c}\text { The actual value of the F-criterion is } \\
\text { greater than the tabular one, the } \\
\text { coefficient of determination is } \\
\text { statistically significant }\end{array}$ \\
\hline
\end{tabular}

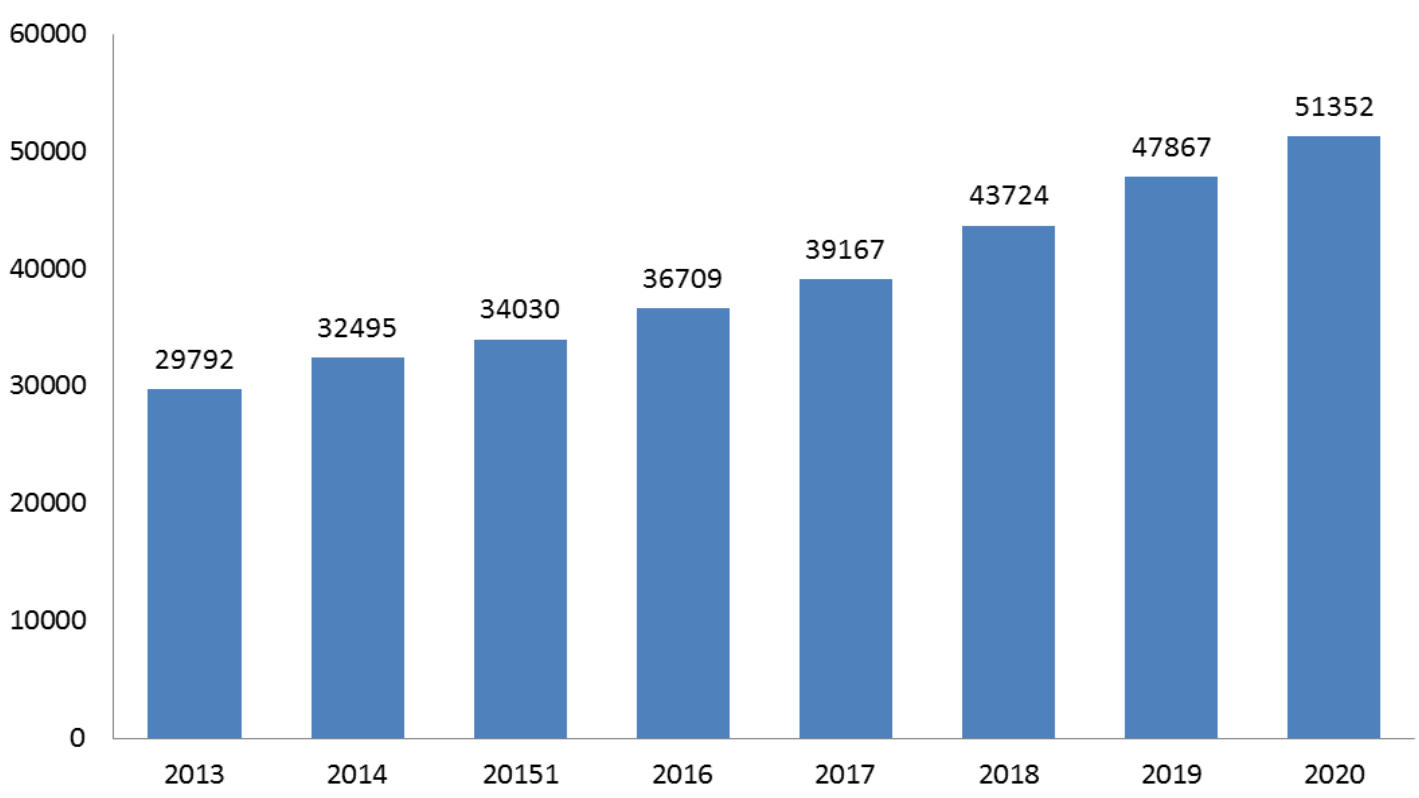

Figure 10. An average annual nominal salary in the Russian Federation in 2013-2020, thousand rubles

Table 7. Relationship assessment the average nominal salary and the amount of personal income tax, 01.01.2013 - 01.05.2021

\begin{tabular}{|c|c|c|c|c|c|}
\hline $\begin{array}{c}\text { Pearson } \\
\text { coefficient }\end{array}$ & $\begin{array}{c}\text { Communication } \\
\text { tightness on the } \\
\text { Chaddock scale }\end{array}$ & $\mathbf{R}^{2}$ & $\begin{array}{c}\text { Actual F- } \\
\text { score }\end{array}$ & $\begin{array}{c}\text { F-test table } \\
\text { value }\end{array}$ & Output \\
\hline 0,843557958 & high & 0,711590029 & 244,2613638 & 3,937116707 & $\begin{array}{c}\text { The actual value of the F-criterion is greater } \\
\text { than the tabular one, the coefficient of } \\
\text { determination is statistically significant }\end{array}$ \\
\hline
\end{tabular}


Table 8. Relationship assessment the average nominal salary and the amount of personal income tax payments for certain types of income, 01.01.2013 - 01.05.2021

\begin{tabular}{|c|c|c|c|c|c|}
\hline $\begin{array}{c}\text { Pearson } \\
\text { coefficient }\end{array}$ & $\begin{array}{c}\text { Communication } \\
\text { tightness on the } \\
\text { Chaddock scale }\end{array}$ & $\mathbf{R}^{\mathbf{2}}$ & $\begin{array}{c}\text { Actual F- } \\
\text { score }\end{array}$ & $\begin{array}{c}\text { F-test table } \\
\text { value }\end{array}$ & Output \\
\hline 0,077183576 & - & 0,005957304 & 0,593307651 & 3,937116707 & $\begin{array}{c}\text { The actual value of the F-criterion is less } \\
\text { than the tabular value, the coefficient of } \\
\text { determination is statistically insignificant }\end{array}$ \\
\hline
\end{tabular}

Table 9. Relationship assessment the average nominal salary and the amount of property tax paid by individuals, 01.01.2013 - 01.05.2021

\begin{tabular}{|c|c|c|c|c|c|}
\hline $\begin{array}{c}\text { Pearson } \\
\text { coefficient }\end{array}$ & $\begin{array}{c}\text { Communication } \\
\text { tightness on the } \\
\text { Chaddock scale }\end{array}$ & $\mathbf{R}^{2}$ & $\begin{array}{c}\text { Actual F- } \\
\text { score }\end{array}$ & $\begin{array}{c}\text { F-test table } \\
\text { value }\end{array}$ & Output \\
\hline 0,161319445 & low & 0,026023963 & 2,645211247 & 3,937116707 & $\begin{array}{c}\text { The actual value of the F-criterion is less } \\
\text { than the tabular value, the coefficient of } \\
\text { determination is statistically insignificant }\end{array}$ \\
\hline
\end{tabular}

Table 10. Relationship assessment between the average nominal salary and the amount of land tax paid by individuals, 01.01.2013 - 01.05.2021

\begin{tabular}{|c|c|c|c|c|c|}
\hline $\begin{array}{c}\text { Pearson } \\
\text { coefficient }\end{array}$ & $\begin{array}{c}\text { Communication } \\
\text { tightness on the } \\
\text { Chaddock scale }\end{array}$ & $\mathbf{R}^{2}$ & $\begin{array}{c}\text { Actual F- } \\
\text { score }\end{array}$ & $\begin{array}{c}\text { F-test table } \\
\text { value }\end{array}$ & Output \\
\hline 0,347186615 & moderate & 0,120538546 & 13,56889033 & 3,937116707 & $\begin{array}{c}\text { The actual value of the F-criterion is greater } \\
\text { than the tabular one, the coefficient of } \\
\text { determination is statistically significant }\end{array}$ \\
\hline
\end{tabular}

Table 11. Relationship assessment between the average nominal salary and the amount of paid transport tax, 01.01.2013 - 01.05.2021

\begin{tabular}{|c|c|c|c|c|c|}
\hline $\begin{array}{c}\text { Pearson } \\
\text { coefficient }\end{array}$ & $\begin{array}{c}\text { Communication } \\
\text { tightness on the } \\
\text { Chaddock scale }\end{array}$ & $\mathbf{R}^{2}$ & $\begin{array}{c}\text { Actual F- } \\
\text { score }\end{array}$ & $\begin{array}{c}\text { F-test table } \\
\text { value }\end{array}$ & Output \\
\hline 0,253650011 & low & 0,064338328 & 6,807476098 & 3,937116707 & $\begin{array}{c}\text { The actual value of the F-criterion is greater } \\
\text { than the tabular one, the coefficient of } \\
\text { determination is statistically significant }\end{array}$ \\
\hline
\end{tabular}

4. Tax and property of individuals and the number of court cases to appeal the cadastral value of real estate.

The natural response of households to often inadequate assessment of the cadastral value of property is a legal action to change it. These statistics are provided by the territorial divisions of Rosreestr (Figure 12) [35].

2014 became economically difficult for Russian households due to the fall in oil prices and the subsequent devaluation of the ruble. That's why households quickly responded by trying to optimize their property tax payments.

We now recognize more clearly than ever the existence of a strong relationship between these indicators. Households mostly optimize the amount of property tax and clearly react to changes in tax legislation (Table 12). It is worth noting that the reaction has a time lag. The calculation of the amounts of tax payments at the cadastral value was introduced in 2015, and a significant increase in the number of claims occurred only in 2019.

\section{GINI index}

Rosstat provides official data on the value of this coefficient. Calculations show that there is a significant inverse relationship between the amount of taxes paid by households and the stratification of society in accordance with the Gini coefficient (Table 13). It is important to note that the absolute value of the coefficient remains at an extremely high level. That seems a multi-year problem for Russian society. 


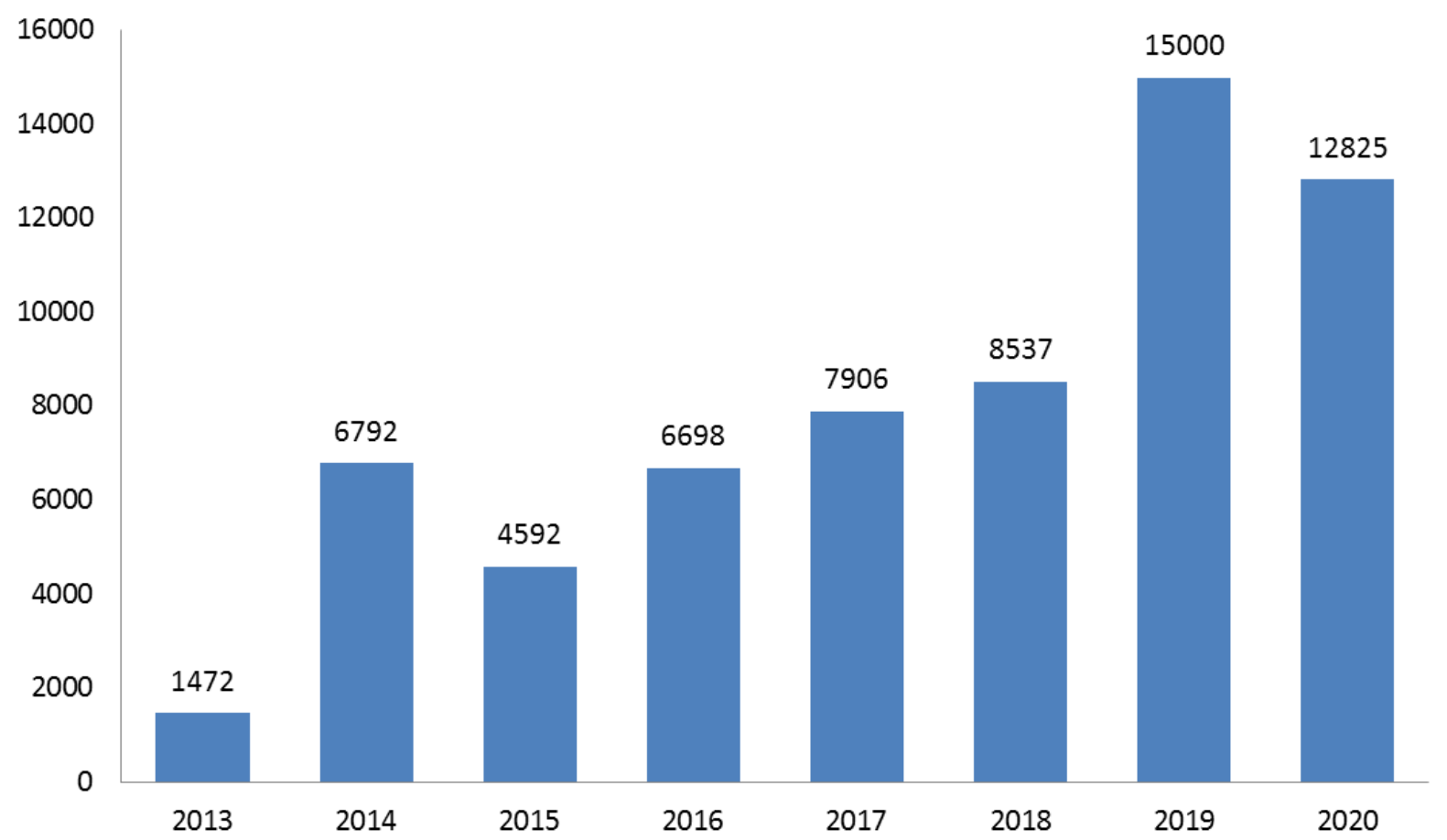

Figure 12. The number of litigations to challenge the cadastral value of real estate of individuals, 2013-2020

Table 12. Relationship assessment between the number of lawsuits challenging the cadastral value and the amount of property tax paid by individuals, $2013-2020$

\begin{tabular}{|c|c|c|c|c|c|}
\hline $\begin{array}{c}\text { Pearson } \\
\text { coefficient }\end{array}$ & $\begin{array}{c}\text { Communication } \\
\text { tightness on the } \\
\text { Chaddock scale }\end{array}$ & $\mathbf{R}^{2}$ & $\begin{array}{c}\text { Actual F- } \\
\text { score }\end{array}$ & $\begin{array}{c}\text { F-test table } \\
\text { value }\end{array}$ & Output \\
\hline 0,902927327 & very high & 0,815277759 & 26,48119965 & 5,987377584 & $\begin{array}{c}\text { The actual value of the F-criterion is } \\
\text { greater than the tabular one, the } \\
\text { coefficient of determination is } \\
\text { statistically significant }\end{array}$ \\
\hline
\end{tabular}

Table 13. Relationship assessment between total taxes paid by households and the Gini coefficient, 2013 - 2020

\begin{tabular}{|c|c|c|c|c|c|}
\hline $\begin{array}{c}\text { Pearson } \\
\text { coefficient }\end{array}$ & $\begin{array}{c}\text { Communication } \\
\text { tightness on the } \\
\text { Chaddock scale }\end{array}$ & $\mathbf{R}^{2}$ & $\begin{array}{c}\text { Actual F- } \\
\text { score }\end{array}$ & $\begin{array}{c}\text { F-test table } \\
\text { value }\end{array}$ & Output \\
\hline$-0,827507652$ & high & 0,684768915 & 13,03365589 & 5,987377584 & $\begin{array}{c}\text { The actual value of the F-criterion is } \\
\text { greater than the tabular one, the } \\
\text { coefficient of determination is } \\
\text { statistically significant }\end{array}$ \\
\hline
\end{tabular}

\section{Conclusions}

The obtained results allow making several conclusions on the households' tax behavior:

1. In world researches on households' responses to changes in taxation scientists focused on a few substantive topics: the response of households to changes in tax incentives; tax behavior of households with different income levels; construction of mathematical models describing the features of the behavior of households in the tax area. According to results of these studies, the identified features of households' behavior should be used to modernize countries' tax policies in the view of academics and researchers. Because of ineffective tax regulation measures the key effects of behavioral finance from section 2 are used by public authorities to modernize a measure of the impact on receptive to them households.

2. As far the tax legislation of household taxation in Russia, the number of changes from 2006 to 2021 was uneven, while 2014, 2015, 2016, 2021 have the most important changes. There is, for instance, a progressive scale of taxation of personal income tax, the new calculation of land taxes and property taxes in accordance with the cadastre data, and increasing transport tax coefficients for luxury cars. In parallel, the introduced pension reform is increasing the rate of value added tax. Thus, considering other economic problems, a strong reaction from Russian households to these changes in taxation could be expected.

3. In the scientific community there is an established research methodology for such studies. Firstly, scientists calculate the coefficient of elasticity of tax payments 
depending on various factors. This method certainly allows obtaining accurate and scientifically valid results. The second method of correlation coefficients is used for the calculations in which the sample could not be representative. Likewise, in Russia there are few sources of statistics concerning the tax behavior of households. Mainly, statistics of the Federal Tax Service of the Russian Federation only for monthly tax payments are available. Indicators of granted tax credits and deductions are available only on an annualized basis. That makes analysis of the elasticity practically impossible.

Hence, using the Pearson coefficient allows us to estimate the correlation between various economic indicators and household tax payments. It is established that the Russian households tend to react with a certain time lag to changes in tax legislation. This effect of temporary discounting is well illustrated by the dynamics of property tax of individuals. For instance, in 2014 the calculation of the tax by the cadastral registration data was introduced, but the reaction to this in the form of appeals to the court was noted only in 2018-2019. As well as, the dynamics of tax payments on personal income tax illustrates the effect of the status quo, when households are not inclined to optimize personal taxation.

4. The comparative analysis leads to some interesting variations in the assessment of the relationship.

The effect of social comparison manifests itself in assessment of the relationship, such as the overall amount of tax, paid by the Russian households, and the Quality of Life Index by Country between 2013 and 2020. A strong link on the Chaddock scale shows that, as living conditions improve, households tend to pay more taxes. Indeed, it sounds quite reasonable with reference to a social contract, but that does not have a rationale in optimizing personal taxation. Likewise, the total cash income of Russian households and the amount of taxes paid between 2013 and 2020 have a strong link on the Chaddock scale. In that case, there had to be a full linear correlation with the relationship of the size of nominal salaries and household taxes. However, it is opposite of the expected result.

Calculation data of the average nominal salary and the amount of property tax, land, and transport tax paid from 01.01.2013 to 01.05.2021 show that there is no connection. Households are most unlikely to be inclined to pay these taxes on salaries.

Some variations in indicators discovered by us may be due to the automatic nature of the provision of standard, social deductions that shows the government's policy to overcome the status quo effect and achieve a satisfactory.

5 . The outcomes of the conducted research can be used for the purposes of implementing the state tax policy. For instance, this can be used in the strategy "Main directions of budgetary, tax and customs-tariff policy" of the Ministry of Finance of the Russian Federation. Nevertheless, at the moment, none of economic development forecasts in the Russian Federation provides for a multi-stage dialogue with households. The forecasts contain measures and the result of state influence on households, but there is not the nature and reasons of their reaction to the measures.

In this study, we managed to systematize the scattered data of Russian official statistics and assessed the response of households to changes in tax policy. As a result, Russian households are prone to behavioral deviations. However, the extent of these deviations and the impact on the financial situation of households' remains to be clarified in future studies.

\section{Acknowledgments}

The reported study was funded by RFBR, project number 19-310-90055.

\section{REFERENCES}

[1] «List of major changes in tax 2006-2021», Consultant Plus, http://www.consultant.ru/ (accessed Aug. 12, 2021)

[2] Galina S., «Increase in the VAT rate and its impact on the buyer», Bulletin of the Moscow State Regional University. Series: Economics, vol. 210, pp. 142-150, 2018. DOI: $10.1051 /$ e3sconf/202021013028

[3] Daniel K., Jack L. K., Richard H. T., «Anomalies: The Endowment Effect, Loss Aversion, and Status Quo Bias», Journal of Economic Perspectives, vol. 5, no. 1, pp. 193206, 1991. DOI: 10.1257/jep.5.1.193

[4] Amos T., Eldar S., «Choice under Conflict: The Dynamics of Deferred Decision», Psychological Science, vol. 3, no. 6, pp. 358-361, 1992. DOI: 10.1111/j.14679280.1992.tb00047.x

[5] Daniel K., Jack L. K., Richard H. T., «Experimental tests of the endowment effect and the coase theorem», Journal of Political Economy, vol. 98, no. 6, pp. 1325-1348, 1990. DOI: $10.1086 / 261737$

[6] Shane F., George L., Ted O'D., «Time Discounting and Time Preference: A Critical Review», Journal Of Economic Literature, vol. 40, no. 2, pp. 351-401, 2002. DOI: $10.1257 / 002205102320161311$

[7] Daniel C. F., «The Development and Enforcement of Group Norms», The Academy of Management Review, vol. 9, no. 1, pp. 47-53, 1984. DOI: 10.2307/258231

[8] Michel J.J.H., Margriet A.Van L. de J., Kirstin C.A., «Public praise vs. private pay: Effects of rewards on energy conservation in the workplace», Ecological Economics, vol. 86, pp. 86-92, 2013. DOI: 10.1016/j.ecolecon.2012.11.008

[9] Robert Andrew W., «Essays on Behavioral Responses to Taxation», Graduate Theses and Dissertations Economics, 2016.

[10] Gerald A., Robert C., «The Effect of Income Taxes on Household Income», The Review of Economics and Statistics, vol. 81, no. 4, pp. 681-693, 1999. DOI: 10.1162/003465399558409

[11] David J., «The Behavioral Response of Wealth Accumulation to Estate Taxation: Time Series Evidence», National Tax Journal, vol. 59, no. 2, pp. 570-583, 2006. 
DOI: $10.17310 / \mathrm{ntj} .2006 .2 .04$

[12] Nigar H., Gareth M., Binh T.-N., «Applications of behavioural economics to tax evasion», Journal of Economic Surveys, vol. 27, no. 5, pp. 941-977, 2013. DOI: $10.1111 / \mathrm{j} .1467-6419.2012 .00733 . \mathrm{x}$

[13] Christophe S., «Tax measures and household financial behaviour: Evidence from France», The Quarterly Review of Economics and Finance, vol. 66, pp. 127-135, 2017. DOI: $10.1016 /$ j.qref.2017.01.013

[14] Poterba J. M., «Taxation, risk-taking, and household portfolio behavior», Handbook of Public Economics, ed. 1, vol. 3, ch. 17, pp. 1109-1171, 2002. DOI: 10.3386/w8340

[15] Nada E., Hilary W. H., «Behavioral Responses to Taxes: Lessons from the EITC and Labor Supply», Tax Policy and the Economy, vol. 20, pp. 73-110, 2006. DOI: 10.1086/tpe.20.20061905

[16] «Understanding the Behavioural Effects from Income Tax Changes», Chief Economist Directorate of the Scottish Government, https://www.gov.scot/publications/ (accessed Aug. 1, 2021)

[17] Jean A., Donal L., «Implications Of Behavioural Economics For Tax Policy», An Roinn Airgeadais Department Of Finance, https://igees.gov.ie/wpcontent/uploads/2014/01/Behavioural-Economics-andTax.pdf (accessed Aug. 4, 2021)

[18] Stewart K., Marco H., Simon R., Michael S., «Behavioral Interventions in Tax Compliance», World Bank Group. Policy Research Working Paper, no. 7690, 2016. DOI: 10.1596/1813-9450-7690

[19] William J. C., Jeffrey R. K., Sendhil M., «Behavioral Economics and Tax Policy», National Tax Journal, vol. 62, no. 3, 2009. DOI: 10.17310/ntj.2009.3.01

[20] Michal G.-W., Blair D. R., William G. G., Clinton K., Dan A., «Behavioral interventions to increase tax-time saving: Evidence from a national randomized trial», Journal of Consumer Affair, vol. 51, no. 1, pp. 3-26, 2016. DOI: 10.1111/joca.12114

[21] Nina R., Ana Maria Rojas M., Carlos S., «Behavioral Insights for Foresighted Public Finance», Inter-American Development Bank (IDB),

https://publications.iadb.org/publications/english/documen t/Behavioral_Insights_for_Foresighted_Public_Finance.pd f (accessed Aug. 27, 2021)

[22] Rajeev C., «A Behavioral Economics Perspective on Tobacco Taxation», Am J Public Health, vol. 100, no. 4, pp. 609-615, 2010. DOI: 10.2105/AJPH.2009.160838

[23] Emmanuel S., Joel B. S., Seth H. G., «The Elasticity Of Taxable Income With Respect To Marginal Tax Rates: A Critical Review», Journal of Economic Literature, American Economic Association, vol. 50, no. 1, pp. 3-50, 2009. DOI: $10.3386 /$ w15012

[24] M. Chatib B., Mayara F., Rema H., Benjamin A. O., «Tax Administration vs. Tax Rates: Evidence from Corporate Taxation in Indonesia», American Economic Review, https://www.aeaweb.org/journals/aer/forthcoming (accessed Aug. 1, 2021)

[25] Daniel K. T., Abel F., Eric O. A., Emmanuel E. A. «Buoyancy and Elasticity of Tax: Evidence From Ghana», Journal of Monetary and Economic Integration, vol. 10, no.2, pp. 36-70, 2010.

[26] Nurun N. C., «Measuring the Elasticity of Tax Revenue: A Divisia Index Approach», International Monetary Fund, $\begin{array}{llll}\text { vol. } 1, \quad \text { pp. } & \text { 87-122, } 1979 . & \text { DOI: }\end{array}$ $10.5089 / 9781451956528.024$

[27] James S. C., Paolo S., «Household Debt and the Dynamic Effects of Income Tax Changes», The Review of Economic Studies, vol. 84, pp. 45-81, 2017. DOI: 10.1093/restud/rdw021

[28] Alexander L., Michael S., «To Cut or Not to Cut? On the Impact of Corporate Taxes on Employment and Income», Finance and Economics Discussion Series (FEDS), 2016. DOI: 10.17016/FEDS.2016.006

[29] Chris E., «Tax Reform and Interstate Migration», Tax And Budget Bulletin, https://www.cato.org/tax-budgetbulletin/tax-reform-interstate-migration (accessed Aug. 27, 2021)

[30] Charles S., «The Effect of Tax Changes on Consumer Spending», Current Issues IN Economics and Finance, vol. 7, no. 11, 2001. DOI: $10.2139 /$ ssrn. 711385

[31] Jason F., «Correlation Coefficient», Investopedia, https://www.investopedia.com/terms/c/correlationcoefficie nt.asp (accessed Aug. 4, 2021)

[32] «The magnitude and strength of the correlation coefficient», Statpsy, https://statpsy.ru/correlation/velicina/ (accessed Aug. 27, 2021)

[33] «F-statistics. Fisher's criterion», Math.Semestr, https://math.semestr.ru/corel/fisher.php (accessed Aug. 27, 2021)

[34] «Tax Code of the Russian Federation (part two)», Consultant Plus, http://www.consultant.ru/document/cons_doc_LAW_2816 5/f905a0b321f08cd291b6eee867ddfe62194b4115/ (accessed Aug. 27, 2021)

[35] «General Information On Resolution Of Disputes About The Results Of Determining The Cadastre Value In Courts», Federal Service for State Registration, Cadastre and Cartography (Rosreestr), https://rosreestr.gov.ru/site/activity/informatsiya-osudebnykh-sporakh-v-otnoshenii-rezultatov-opredeleniyakadastrovoy-stoimosti-obektov-/ (accessed Aug. 4, 2021)

[36] «Europe: Quality of Life Index by Country 2013-2020», Nunbeo, https://www.numbeo.com/quality-oflife/rankings_by_country.jsp?title=2013-Q1\&region=150 (accessed Aug. 27, 2021)

[37] «Russia in numbers 2006-2020», Federal State Statistics Service, https://rosstat.gov.ru/folder/210/document/12993 (accessed Aug. 27, 2021) 